\title{
Development of Gel Phantom Having Dielectric Property Equal to Breast Tissue for Medical Metrology and the Effect of SiC Nanopowders on the Dielectric Constant
}

\author{
Tarık KARABEY ${ }^{1 *}$ (D) , Mehmet ERTUĞRUL ${ }^{2}$ (D) , Hayrettin EROĞLU ${ }^{3} \mathbb{D}$ \\ 1Atatürk University Faculty of Engineering, Department of Nanoscience and Nano Engineering \\ 2Atatürk University Faculty of Engineering, Department of Electrical and Electronics Engineering \\ 3Erzurum Technical University Faculty of Engineering, Department of Chemical Engineering, Erzurum 25050, \\ Turkey
}

Geliş / Received: 31.08.2019, Kabul / Accepted: 15.12.2019

\begin{abstract}
There are major shortcomings of phantoms, which are important for improving the image quality of medical devices produced by developing technology and also for calibration settings. The most important of these shortcomings is the change in the concentration of the structures forming the phantom and the deterioration of the structure due to external factors. It is important to design and develop gel phantoms which are longer time resistant to these negative effects and show electrical properties close to the living tissue. As is the case in many areas, the use of live human subjects in the medical field has not been approved and banned by many ethics committees due to the possibility of being harmful to health, and instead of living human subjects, phantoms with close features are used. In imaging systems, such as MR, Ultrasound, Tomography, X-ray, the working range of these phantoms should be determined. In addition, the use of mobile telephones has been widely used today, the absorption of electromagnetic rays emitted from these devices (SAR) as a result of the loss of the electrical property of phantom to determine the interval of distortion is important for future advances and innovations in the medical field.

In the study, $5 \mathrm{~g}$ PVA was heated in a beaker containing $45 \mathrm{ml}$ of pure water for 5 minutes at $80^{\circ} \mathrm{C}$ with stirring and a $10 \%$ buffer PVA solution was prepared. Different amounts of Triton X-100 were added to these buffer solutions and mixed for 15 minutes. After waiting for 24 hours, dielectric constants of gel phantoms were examined at room temperature. Agilent 85070E Network Analyzer and Performance Probe with Short Block were used to measure the dielectric constant. Gel phantoms were obtained showing the dielectric properties of human breast tissue according to the measurements taken in the frequency range 0 to $20 \mathrm{GHz} .10 \mathrm{ml} 10 \%$ PVA $+5 \mathrm{ml}$ Triton X-100 gel phantom from this gel phantom was examined by changing the dielectric constant by mixing $0.1 \mathrm{~g} \mathrm{SiC}$ nanopowder. Afterwards, images of this gel phantom obtained with WETSEM (Wet Scanning Electron Microscope) were examined.
\end{abstract}

Keywords: Medical Metrology, Breast Tissue, Dielectric Property, Gel Phantom, WETSEM

\section{Medikal Metroloji için Meme Dokusuna Dielektrik Özelliği Eş Jel Fantom Üretimi ve SiC Nanotozlarının Dielektrik Sabitine Etkisi}

$\ddot{\mathbf{O} z}$

Gelişen teknoloji ile üretilen medikal cihazların hem görüntü kalitesini arttırmak hem de kalibrasyon ayarları için önemli bir yeri olan fantomların büyük eksikleri bulunmaktadır. Bu eksikliklerden en önemlileri fantomu oluşturan yapıların konsantrasyonunun zamanla değişmesi ve dış etkenlere bağlı olarak yapının bozulmasıdır. Bu olumsuz etkilere karşı daha uzun süre dayanıklı olan ve canlı doku özelliğine yakın elektriksel 


\section{Development of Gel Phantom Having Dielectric Property Equal to Breast Tissue for Medical Metrology and the Effect of SiC Nanopowders on the Dielectric Constant}

özellikler gösteren jel fantomlar tasarlamak ve geliştirmek önemlidir. Birçok alanda olduğu gibi medikal alanda da canlı insan deneklerin kullanılması sağlığa zararlı olma ihtimalinden dolayı birçok etik kurul tarafindan uygun görülmemiştir ve yasaklanmıștır. Canlı insan deneklerin yerine yakın özelliklere sahip fantomlar kullanılmaktadır. Bu fantomların MR, Ultrason, Tomografi, Röntgen gibi görüntüleme sistemlerinde elektriksel özelliklerini kaybettiği çalışma aralığının belirlenmesi gerekir. Buna ek olarak mobil telefonların yaygın olarak kullanıldığı günümüzde bu cihazlardan yayılan elektromanyetik ışınların emilimi (SAR) sonucu fantomun elektriksel özelliğini kaybederek bozulma aralığının saptanması gelecekte medikal alanda yapılacak ilerlemeler ve yenilikler için önemlidir.

Yapılan çalışmada $5 \mathrm{~g}$ PVA, içerisinde $45 \mathrm{ml}$ saf su bulunan bir beherde karıştırma işlemi ile beraber $80^{\circ} \mathrm{C}$ sıcaklıkta 5 dakika 1sıtıldı ve \% 10’luk tampon PVA çözeltisi hazırlandı. Bu tampon çözeltilere farklı miktarlarda Triton X-100 maddeleri eklenerek 15 dakika karıștırıldı. 24 saat beklendikten sonra oda sıcaklığında jel fantomların dielektrik sabitlerine bakıldı. Dielektrik sabitinin ölçümü için Agilent 85070E Network Analiz Cihazı ve Performance Probe ile Short Block kullanıldı. 0 ile $20 \mathrm{GHz}$ frekans aralığında alınan ölçümlere göre insan meme dokusunun dielektrik özelliklerini gösteren jel fantomlar elde edildi. Bu jel fantomlardan $10 \mathrm{ml}$ \%10'luk PVA $+5 \mathrm{ml}$ Triton X-100 jel fantomuna $0,1 \mathrm{gr}$ SiC nanotozu karıştııılarak dielektrik sabitindeki değişim incelendi. Daha sonra elde edilen bu jel fantomun WETSEM (Islak Taramalı Elektron Mikroskobu) ile görüntüleri incelendi.

Anahtar Kelimeler: Medikal Metroloji, Meme Dokusu, Dielektrik Özellik, Jel Fantom, WETSEM

\section{Introduction}

Breast cancer is one of the most important cancers in women. It is the second most common type of cancer among women after skin cancer. Mortality rate among breast cancer patients is the second highest after lung cancer. X-ray mammography can be used in diagnosis in women who have no symptoms of breast cancer by approximately $80-90 \%$. However, mammography uses ionizing radiation, which causes painful pressure and discomfort to the breast. Mammography can be particularly problematic for premenopausal women with intense breast tissue and is not recommended as a general screening method for patients under the age of 40 years. Technologies that use electromagnetic waves in non-ionizing microwave frequencies have emerged as an alternative to detection of breast cancer and treatment with high fever (hyperthermia). The effect of these techniques depends on the correct knowledge of the basic electromagnetic (dielectric) properties of normal, malign and benign breast tissues. (Lazebnik, 2008). Phantoms with similar features of living tissue are produced to calibrate and improve medical imaging devices such as x-ray, ultrasound, MRI and computed tomography very well.

Thanks to the developments in science, great steps have been taken in medical technology. The use of imaging systems using low frequency waves such as microwave is very important for living tissue, because low frequency electromagnetic (EM) waves have no harmful effects on the living tissue (Kottou et al., 2014). Therefore, studies on the design of phantoms that mimic the properties of living tissues in these frequencies have increased. While designing these phantoms, various materials have been used to show the characteristics of different living tissues (MEGEP, 2012).

It is aimed to synthesize gel phantoms which have similar characteristics to the electrical properties of living tissues. Since the living tissues are homogenous or heterogeneous, it is 
intended to make new designs suitable for both structures. The use of electromagnetic waves of medical imaging devices for the purpose of testing and calibration of the gel phantom is intended as the main purpose. This gel phantom must be identical to the electrical properties of human breast tissue. The major disadvantage of gel phantoms is that they suffer from water evaporation and deterioration due to organic contents. It is intended to design a phantom without this disadvantage. This phantom is required to be more resistant to bacteria and external action with its special components. It is aimed to be tested in appropriate environment by making gel phantoms which are identical to human tissue considering all of them. Since the phantoms to be made are in stable structures, the test and calibration of the systems will be made in place. At the same time, because the gel phantoms to be produced will be similar to the electrical properties of living tissues, the quality of the images obtained from the imaging devices will also increase.

In a study conducted with Triton X-100 and pure water mixture, in the frequency range of $0.5-12 \mathrm{GHz} 18-30{ }^{0} \mathrm{C}$, very close to the dielectric properties of the breast tissues, easy to use and cost-effective liquid phantoms were produced. Mixtures of 20, 25, 30, 35 and 40\% concentrations were made at room temperature and kept in a thermostatic bath prior to measurement (Romeo et al., 2011).

In the study using Triton $\mathrm{X}-100$ and saline water, liquid phantoms with close to dielectric constants of normal and tumorous breast tissues were obtained in the frequency band range of 0.5-6 GHz. Gelling was observed in liquid phantoms by varying the temperature and salt concentration. Gelling has occurred at low temperature and mixtures with high salt concentration are not used (Joachimowicz et al., 2016).

In a different study conducted with computer simulation, liquid phantom forming substances were determined. The basis of the simulation is the modeling of linear attenuation coefficient and thickness by modeling a mathematical relationship according to a known material.

According to this model, water, glycerol and isopropyl alcohol were selected. In the simulation, phantoms showing the characteristic of breast tissues in different fat ratios were obtained. In oily tissues, the water content is less than $2 \%$, the glycerol and isopropyl alcohol ratios are $14 \%$ and $85 \%$ respectively. In other tissue groups, water, isopropyl alcohol and glycerol ratios were $43 \%, 34 \%$ and $23 \%$, respectively. (Lam et al., 2014).

In another phantom study, which was formed by mixing sunflower oil, water and gelatin, phantoms mimicking the electrical properties of human breast tissues in the frequency range of $0.5-50 \mathrm{GHz}$ were produced. Changing the concentration of sunflower oil has enabled the production of phantoms that mimic the electrical properties of different breast tissues (Meo et al., 2018, Meo et al., 2019a, Meo et al., 2019b)

Dielectric constants and electrical conductivity of phantoms are used in cancer treatment. For example an article proposes a novel solid breast-tumor phantom for microwave hyperthermia in breast cancer treatment. Most phantom models do not include distinct definitions of tumor and normal tissue. According to tissue dielectric properties reported, in this study researchers performed phantom. A Network Analyzer and Dielectric Probe Kit measured dielectric 
constant and electrical conductivity for both breast normal tissue and tumor phantom. Since the microwave processing frequency is generally $2.45 \mathrm{GHz}$, measurements were made in the 2 to $3 \mathrm{GHz}$ frequency range. At $2.45 \mathrm{GHz}$, the electrical conductivity of the breast phantom was measured $0.1304 \pm$ $0.0680 \mathrm{~S} / \mathrm{m}$ and the dielectric constant was measured $4.4401 \pm 1.2514$.

At the same frequency, the tumor phantom has an electrical conductivity of $2.7015 \pm 0.0783$ $\mathrm{S} / \mathrm{m}$ and a dielectric constant of $55.2566 \pm$ 1.1899. The results presented were highly correlated with the expected values. Therefore, it was thought that this phantom could be used for microwave hyperthermia in breast cancer treatment and antenna performance analysis and optimization (Ortega-Palacios et al., 2010).

In another study evaluation of local tissue water using tissue dielectric constant (TDC) values was useful in assessing oedema / lymphoedema characteristics and changes. Knowledge of tissue depth dependence of the anatomical region and TDC values were thought to extend the utility of that method. The aim of the study was to compare TDC values obtained from anatomically matched regions and to investigate depth dependence. In 22 women (12 awaiting surgery for breast cancer and 10 cancer-free control subjects), four sites (mid-forearm, mid- biceps, axilla and lateral thorax) on both body sides were measured with a $2.5 \mathrm{~mm}$ sampling depth probe. Also, at forearm, four different probes with sampling depths of $0.5,1.5,2.5$ and 5 $\mathrm{mm}$ were used. Composite findings have shown that TDC measurements have the necessary properties to assess the beneficial change in oedema / lymphoedema and limbs and body regions that are not routinely suitable for evaluation of other techniques (Mayrovitz et al., 2008).

\section{Material and Methods}

The dielectric properties of a non-magnetic material such as biological tissues are defined by a dielectric constant and electrical conductivity. Usually two parameters are expressed. The first is the complex dielectric constant which is unitless and is known as complex relative permeability. The complex dielectric constant is expressed as $\mathrm{e}^{*}(\mathrm{w})=$ $e^{\prime}(w)-j e "(w)$. Here $j$ is $j=\sqrt{ }-1$ and $w$ is angular velocity $\mathrm{w}=2 \pi \mathrm{f}(\mathrm{rad} / \mathrm{s})$. In this sense, the dielectric constant and the relative dielectric constant are used interchangeably. The real part of the complex dielectric constant is related to the energy storage capability of the material. Effective conductivity is $\sigma(\mathrm{w})=\mathrm{we} "(\mathrm{w}) \varepsilon 0$. Here $\varepsilon 0=8.854 \mathrm{X} 10-12 \mathrm{~F} / \mathrm{m}$ is the dielectric constant of free space, it is related to the ability of the material to emit electromagnetic energy and is expressed in $\mathrm{S} / \mathrm{m}$ (ohm-1/m). According to the molecular relaxation theory proposed by P.Debye in 1929, the dipoles are directed in a polarized material, which is stimulated by the change of the electromagnetic field over time, and then returns to the steady state, which is expressed by the relaxation time constant $T$. This is the relaxation frequency $\mathrm{fc}$ and $(\mathrm{fc}=2 \pi \mathrm{T})-1$. The mathematically complex dielectric constant is expressed by e*(w) $=\mathrm{e}^{\prime}(\mathrm{w})-\mathrm{je} \mathrm{e}^{\prime \prime}(\mathrm{w})=\mathcal{E}_{\infty} \infty+[\mathcal{E}$ - $\left.\varepsilon_{\infty} / 1+j w T\right]$. Here, $\varepsilon_{\infty}$ dielectric constant at higher frequencies than fc, $\varepsilon$ s dielectric constant is at lower frequencies than $\mathrm{fc}$ and $\mathrm{T}$ is the relaxation time constant of the material (Lazebnik, 2008).

In order to obtain the dielectric constant of the breast tissue phantom, first the solvents must be determined. Therefore, dielectric constants were examined by selecting suitable solvents with high dielectric constant such as pure 
water and PolyVinylAlcohol (PVA). Agilent 85070E Network Analyzer was used to measure the dielectric constant. Dielectric constants were measured by immersing the tip of the Network Analyzer Performance Probe in phantoms. The instrument was calibrated before each measurement. In addition, the dielectric constant was changed by adding Triton X-100 with low dielectric constant. Triton X-100 can be used as phantom material in mobile phone frequencies and narrow band frequency applications (Romeo et al., 2011).

Table 2.1. Mass components of gel phantoms made with PVA, pure water and Triton X-100

\begin{tabular}{|c|c|c|c|}
\hline Sample & PVA (g) & $\begin{array}{c}\text { Pure } \\
\text { water } \\
(\mathbf{m l})\end{array}$ & $\begin{array}{c}\text { Triton X- } \\
\mathbf{1 0 0}(\mathbf{m l})\end{array}$ \\
\hline $\mathrm{a}$ & 5 & 45 & - \\
\hline $\mathrm{b}$ & 5 & 45 & 1 \\
\hline $\mathrm{c}$ & 5 & 45 & 2 \\
\hline $\mathrm{d}$ & 5 & 45 & 3 \\
\hline $\mathrm{e}$ & 5 & 45 & 4 \\
\hline $\mathrm{f}$ & 5 & 45 & 5 \\
\hline $\mathrm{g}$ & 5 & 45 & 6 \\
\hline $\mathrm{h}$ & 5 & 45 & 7 \\
\hline 1 & 5 & 45 & 8 \\
\hline
\end{tabular}

Xia et al. performed PVA Hydrogel phantom in solid and molten aqueous PVA solutions in photoacoustic imaging. They have obtained the material which acoustic and optical properties of the material close to the tissue.

Firstly $5 \mathrm{~g}$ PVA was heated in a beaker containing $45 \mathrm{ml}$ of pure water for 5 minutes at $80{ }^{\circ} \mathrm{C}$ with stirring and $\% 10$ buffer PVA solution was prepared. Different amounts of
Triton X-100 have been added to $10 \mathrm{ml}$ of PVA solutions and mixed for 15 minutes to ensure homogeneity. Dielectric constants were measured after waiting 24 hours. According to the measurements taken at room temperature between 0 and $20 \mathrm{GHz}$ frequency, gel phantoms which are very close to dielectric properties of human breast tissue were obtained.
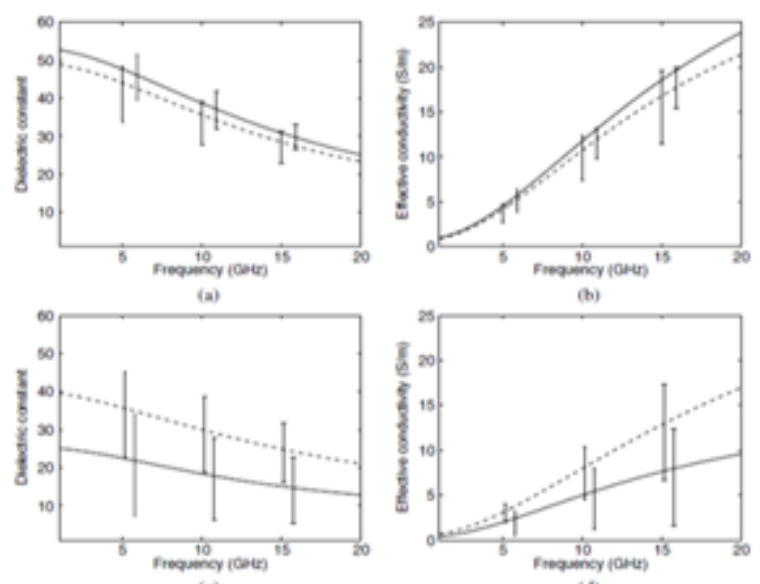

(b)
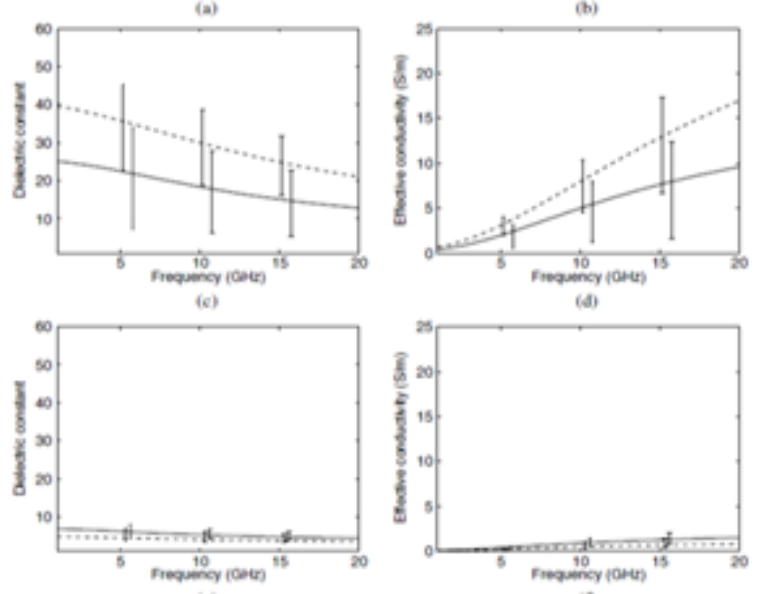

(6)

Figure 3.1. Dielectric constant and conductivity changes of normal and cancerous breast tissue groups in Cole-Cole diagram. a-b) Group 1 (\%0-30 fatty) c-d) Group 2 (\%31-84 fatty) e-f) Group 3 (\%85-100 fatty) * dashed line is normal tissue, flat line is cancerous tissue (Lazebnik et.al., 2007) 


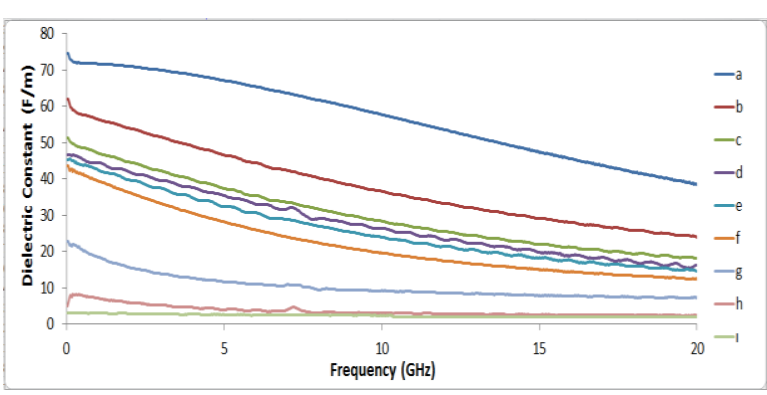

Figure 3.2. Variation of dielectric constants depending on the frequency of gel phantoms made with PVA, pure water and Triton X-100. (Gel phantoms made according to Table 2.1.)

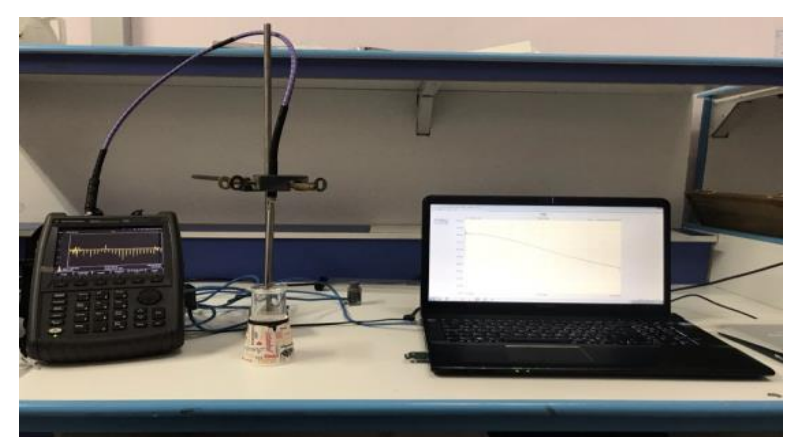

Figure 3.3. The experimental set up to measure dielectric constant

\section{Conclusion and Discussion}

Breast tissue consists of three groups: low-fat (group 1), medium-fat (group 2) and very fatty (group 3) (Lazebnik, 2008). Figure 3.1 shows the dielectric constant and conductivity curves obtained from measurement of normal and cancerous tissue samples in the graphs. Dielectric constants of breast tissue gel phantoms made with PVA, pure water and Triton X-100 were measured and the graph in Figure 3.2 showed frequency-dependent changes. As a result of the studies, the most suitable gel phantoms are 10\% PVA + 2,3,5,6,7 and $8 \mathrm{ml}$ Triton X-100 gel phantoms. (Figure 3.4., Figure 3.8., Figure 3.11.). Then, $10 \mathrm{ml} \mathrm{5 \%} \mathrm{PVA} \mathrm{solutions} \mathrm{were} \mathrm{prepared} \mathrm{to}$ examine the deterioration times of the phantoms. Thereafter, $0.5,1,1.5$ and $2 \mathrm{ml}$ Triton X-100 was added and 4 gel phantoms were obtained. There were no significant changes in the dielectric constants of the phantoms in these measurements after 3, 4 and 8 weeks after these phantoms (Figures 3.15.,3.16., 3.17. and 3.18.).

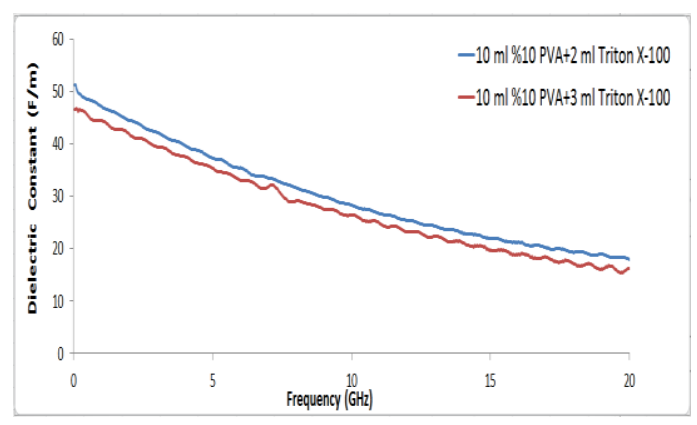

Figure 3.4. $10 \mathrm{ml} 10 \%$ PVA solution $+2 \mathrm{ml}$ Triton $\mathrm{X}-100$ and $10 \mathrm{ml} 10 \%$ PVA solution $+3 \mathrm{ml}$ Triton X-100 dielectric constants in the frequency range of gel phantoms with $0-20$ GHz.

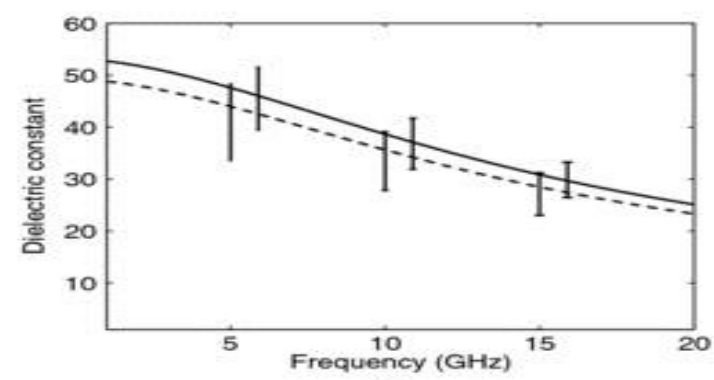

(a)

Figure 3.5. The dielectric constants of group 1 normal and cancerous breast tissues (flat line is cancerous tissue, dashed line is normal tissue)

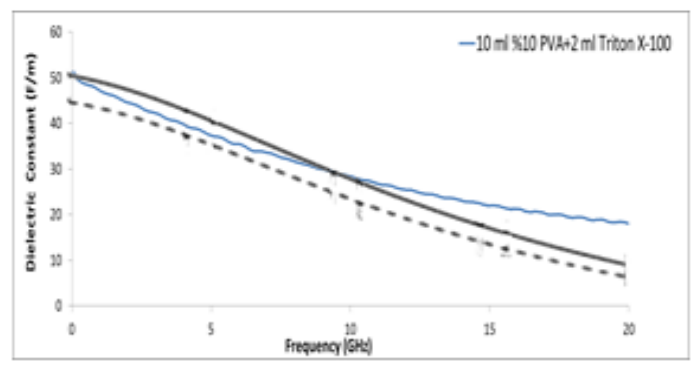

Figure 3.6. Comparison of dielectric constant of $10 \mathrm{ml} 10 \%$ PVA $+2 \mathrm{ml}$ Triton X-100 phantom with dielectric constant of first group cancerous breast tissue. (black flat line is dielectric constant of first group cancerous breast tissue) 
Development of Gel Phantom Having Dielectric Property Equal to Breast Tissue for Medical Metrology and the Effect of SiC Nanopowders on the Dielectric Constant

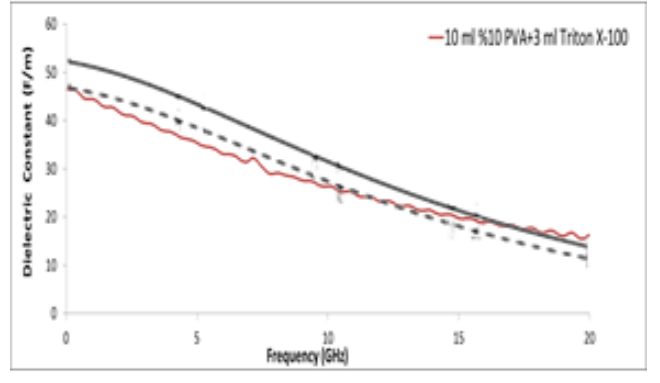

Figure 3.7. Comparison of dielectric constant of $10 \mathrm{ml} 10 \%$ PVA $+3 \mathrm{ml}$ Triton X-100 phantom with the dielectric constant of first group normal breast tissue. (black dashed line is dielectric constant of first group normal breast tissue)

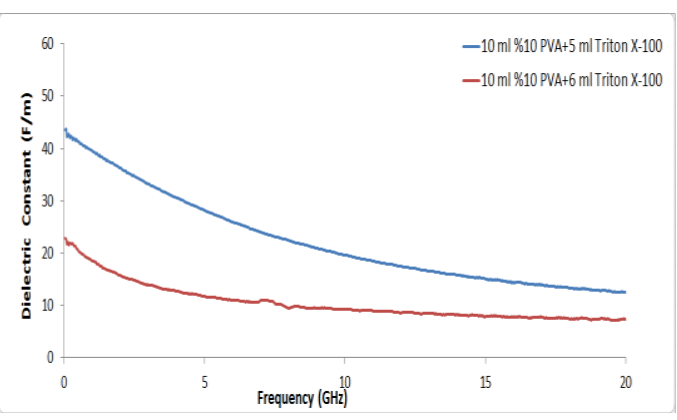

Figure 3.8. Dielectric constants of gel phantom samples which made with $10 \mathrm{ml} 10 \%$ PVA solution $+5 \mathrm{ml}$ Triton X100 and $10 \mathrm{ml}$ 10\% PVA solution $+6 \mathrm{ml}$ Triton X-100.

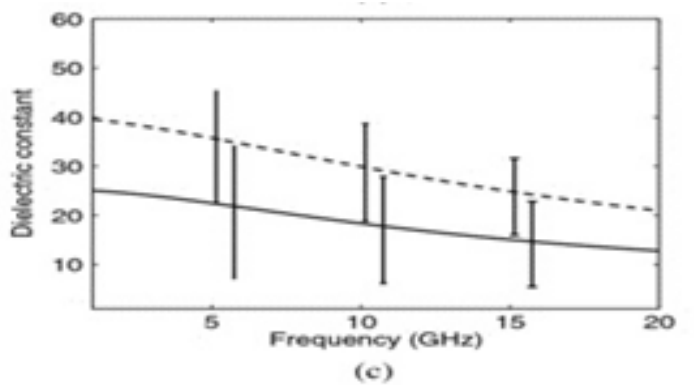

Figure 3.9.Dielectric constants of normal and cancerous breast tissues (flat line is cancerous tissue, dashed line is normal tissue)

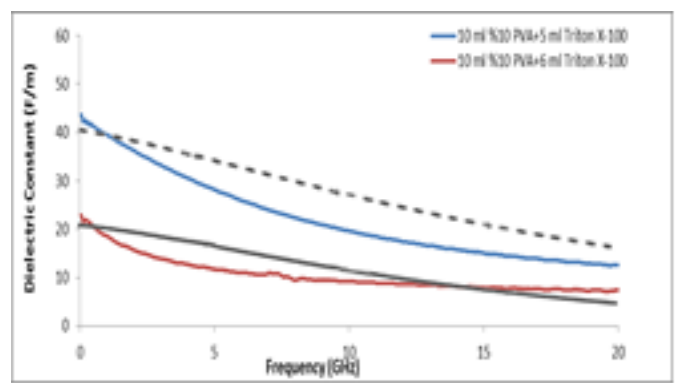

Figure 3.10. Comparison of dielectric constants of $10 \mathrm{ml} \% 10$ PVA $+5 \mathrm{ml}$ Triton X-100 and $10 \mathrm{ml} \% 10$ PVA+6 ml Triton X-100 gel phantoms with dielectric constants of group 2 normal and cancerous breast tissues. (black dashed line is the dielectric constant of second group normal breast tissue, black flat line is the dielectric constant of second group cancerous breast tissue)

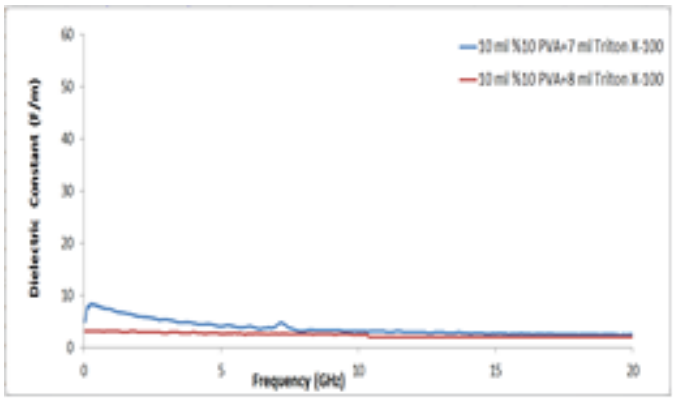

Figure 3.11. Dielectric constants of gel phantom samples made with $10 \mathrm{ml} \% 10$ PVA solution $+7 \mathrm{ml}$ Triton X-100 and $10 \mathrm{ml} \% 10$ PVA solution+8 $\mathrm{ml}$ Triton X-100.

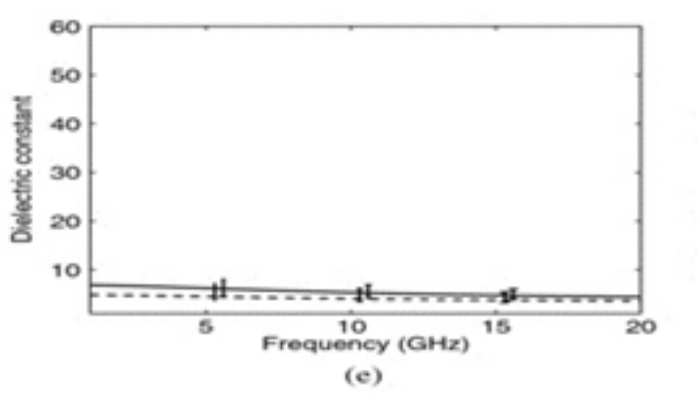

Figure 3.12. Dielectric constants of normal and cancerous breast tissues of third group (flat line is cancerous tissue, dashed line is normal tissue) 
Development of Gel Phantom Having Dielectric Property Equal to Breast Tissue for Medical Metrology and the Effect of SiC Nanopowders on the Dielectric Constant

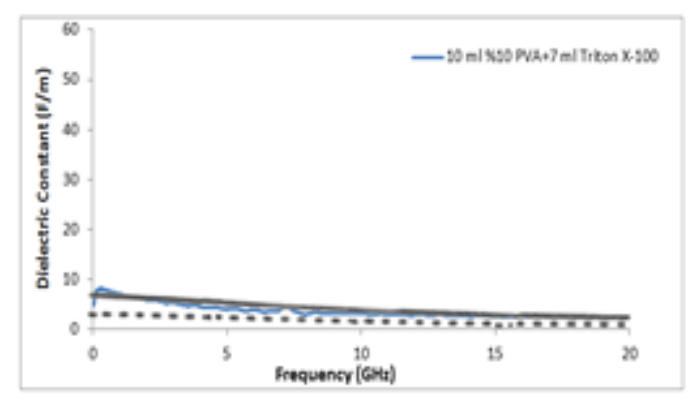

Figure 3.13. Comparison of dielectric constant of $10 \mathrm{ml} 10 \%$ PVA $+7 \mathrm{ml}$ Triton X-100 phantom with dielectric constant of third group cancerous breast tissue. (black flat line is the dielectric constant of third group cancerous breast tissue)

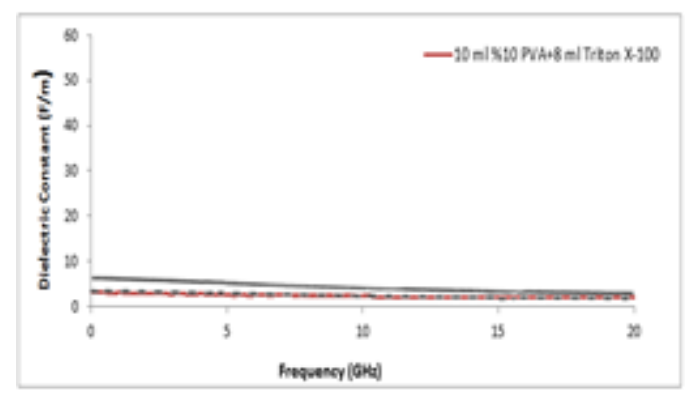

Figure 3.14. Comparison of the dielectric constant of $10 \mathrm{ml}$ $10 \%$ PVA $+8 \mathrm{ml}$ Triton $\mathrm{X}-100$ gel phantom with the dielectric constant of the third group normal breast tissue. (black dashed line is the dielectric constant of third group normal breast tissue)

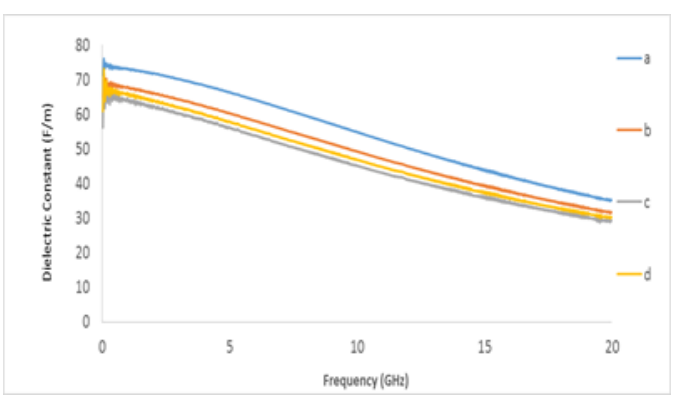

Figure 3.15. Variation of dielectric constants depending on the frequency of phantoms made with PVA, pure water and Triton X-100. (a. $10 \mathrm{ml} \% 5$ PVA solution+ $0.5 \mathrm{ml}$ Triton X100, b. $10 \mathrm{ml} \% 5$ PVA solution+ $1 \mathrm{ml}$ Triton X-100, c. $10 \mathrm{ml}$ $\% 5$ PVA solution+ $1.5 \mathrm{ml}$ Triton X-100, d. $10 \mathrm{ml} \% 5$ PVA solution+ $2 \mathrm{ml}$ Triton X-100 phantoms)

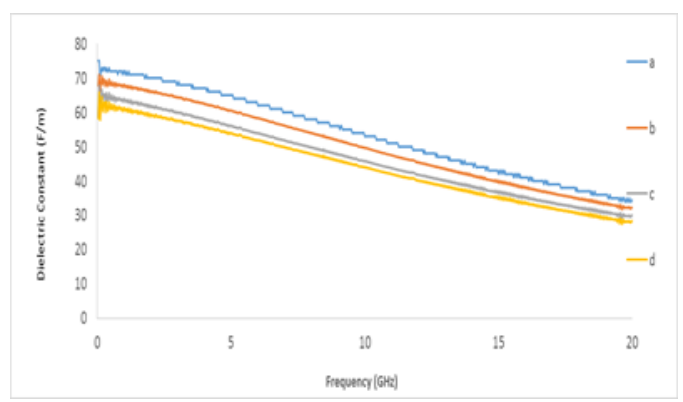

Figure 3.16. The change of dielectric constants depending on the frequency at the end of the third week of phantoms made with PVA, pure water and Triton X-100. (a. $10 \mathrm{ml} \% 5$ PVA solution $+0.5 \mathrm{ml}$ Triton $\mathrm{X}-100$, b. $10 \mathrm{ml} \% 5$ PVA solution+ 1 $\mathrm{ml}$ Triton X-100, c. $10 \mathrm{ml} \% 5$ PVA solution+ $1.5 \mathrm{ml}$ Triton $\mathrm{X}-100$, d. $10 \mathrm{ml} \% 5$ PVA solution+ $2 \mathrm{ml}$ Triton X-100 phantoms)

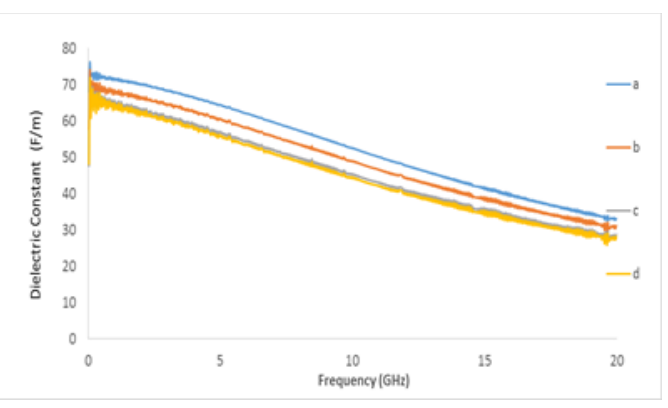

Figure 3.17. The change of dielectric constants depending on the frequency at the end of the fourth week of phantoms made with PVA, pure water and Triton X-100. (a. $10 \mathrm{ml} \% 5$ PVA solution+ $0.5 \mathrm{ml}$ Triton $\mathrm{X}-100$, b. $10 \mathrm{ml} \% 5$ PVA solution+ 1 $\mathrm{ml}$ Triton X-100, c. $10 \mathrm{ml} \% 5$ PVA solution+ $1.5 \mathrm{ml}$ Triton $\mathrm{X}-100$, d. $10 \mathrm{ml} \% 5$ PVA solution+ $2 \mathrm{ml}$ Triton X-100 phantoms)

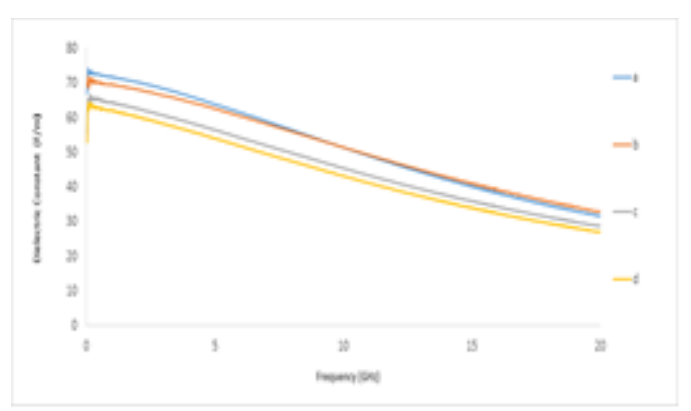

Figure 3.18. PVA, The change of dielectric constants depending on the frequency at the end of the eighth week of phantoms made with PVA, pure water and Triton X-100. (a. $10 \mathrm{ml} \% 5$ PVA solution+ $0.5 \mathrm{ml}$ Triton X-100, b. $10 \mathrm{ml} \% 5$ PVA solution+ $1 \mathrm{ml}$ Triton X-100, c. $10 \mathrm{ml} \% 5$ PVA solution+ $1.5 \mathrm{ml}$ Triton X-100, d. $10 \mathrm{ml} \% 5$ PVA solution+ 2 ml Triton X-100 phantoms) 


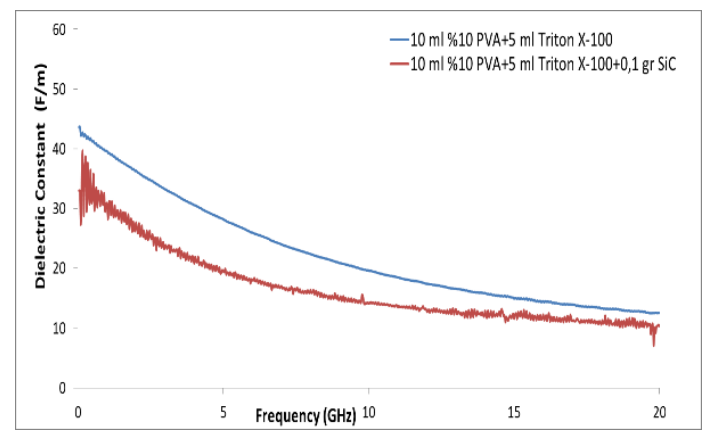

Figure 3.19. Comparison of $10 \mathrm{ml} 10 \% \mathrm{PVA}+5 \mathrm{ml}$ Triton $\mathrm{X}-100$ gel phantom's dielectric constant with $10 \mathrm{ml} 10 \%$ PVA $+5 \mathrm{ml}$ Triton X-100 + 0.1 g SiC gel phantom's dielectric constant.

The change in dielectric constant was observed by adding $0.1 \mathrm{~g} \mathrm{SiC}$ nanopowder to $\% 10$ PVA $+5 \mathrm{ml}$ Triton $\mathrm{X}-100$ phantom which is equivalent to second group normal breast tissue. A decrease in the dielectric constant was observed. Then the gel phantom images was taken on WETSEM device and the distribution of $\mathrm{SiC}$ nanopowder's examined in phantom.

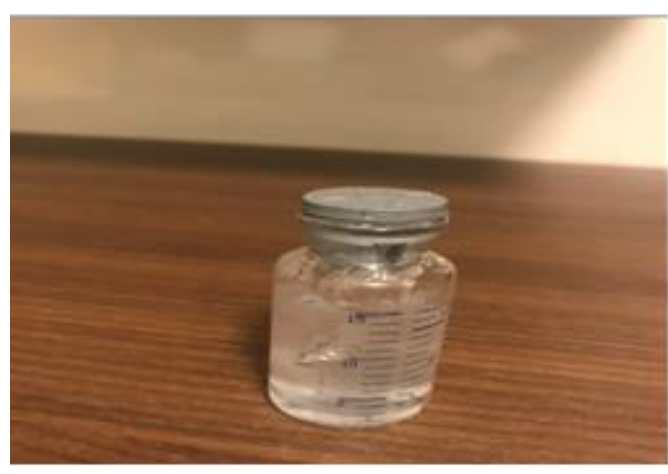

Figure 3.20. One of the prepared gel phantom samples

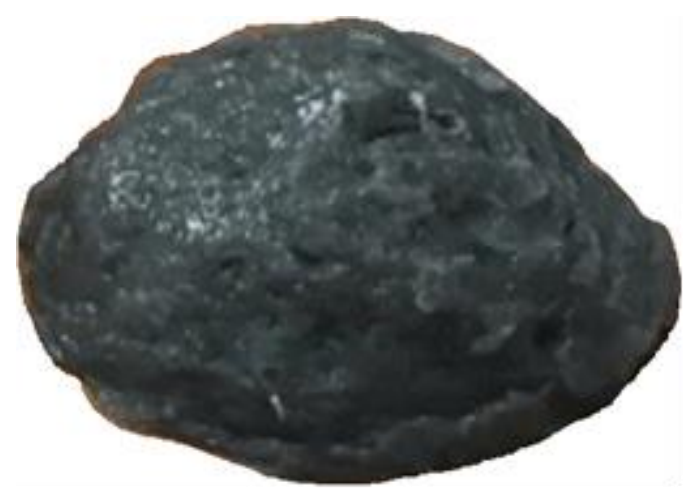

Figure 3.21. Gel phantom with $0.1 \mathrm{~g} \mathrm{SiC}$ nanopowder 
Development of Gel Phantom Having Dielectric Property Equal to Breast Tissue for Medical Metrology and the Effect of SiC Nanopowders on the Dielectric Constant

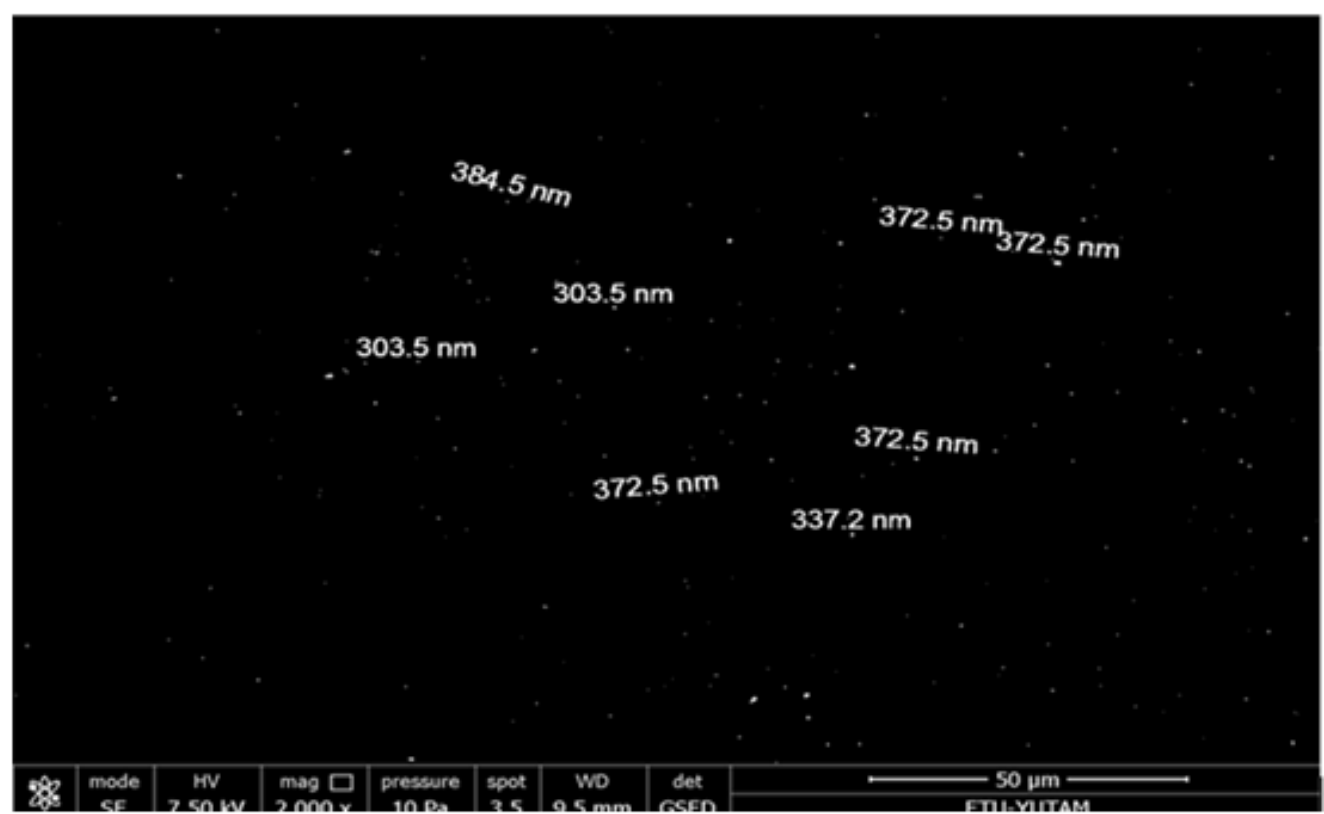

Figure 3.22. Dimensions of the $\mathrm{SiC}$ nanopowders seen in $10 \mathrm{ml} \% 10 \mathrm{PVA}+5 \mathrm{ml}$ Triton $\mathrm{X}-100+0,1 \mathrm{gr} \mathrm{SiC}$ gel phantom in WETSEM device

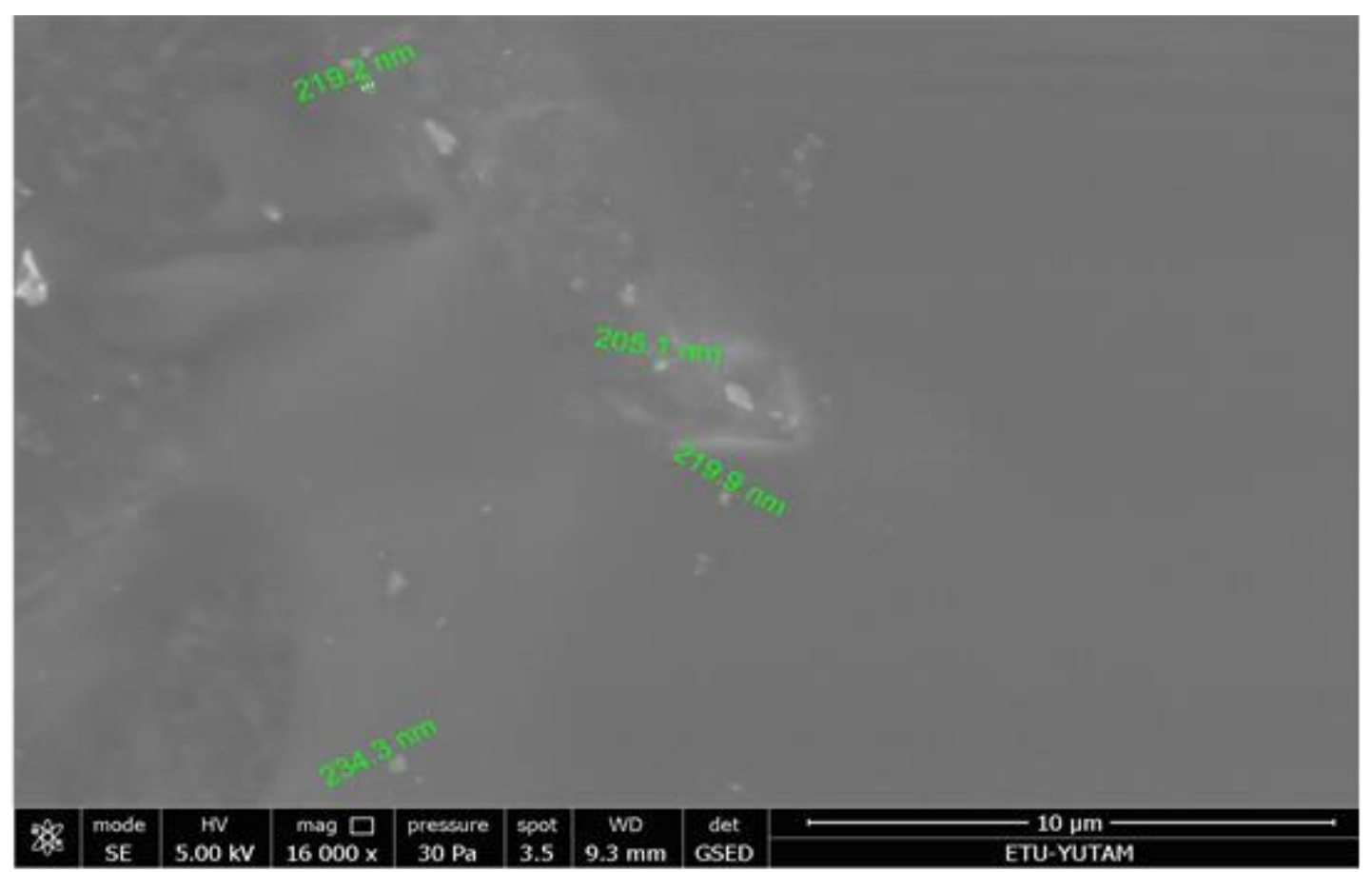

Figure 3.23. Dimensions of the $\mathrm{SiC}$ nanopowders seen in $10 \mathrm{ml} \% 10 \mathrm{PVA}+5 \mathrm{ml}$ Triton $\mathrm{X}-100+0,1 \mathrm{gr} \mathrm{SiC}$ gel phantom in WETSEM device 


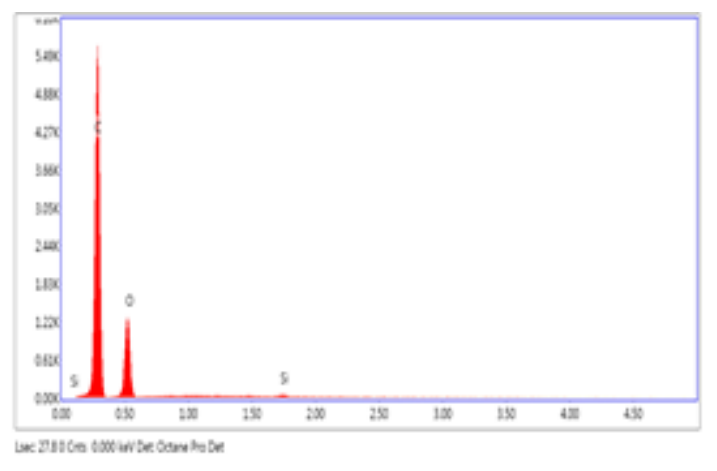

Figure 3.24. The result of EDX analysis from the surface in Figure 3.25.

Particles ranging in size from 200 to $400 \mathrm{~nm}$ observed in Figures 3.22. and 3.23. are interpreted as dispersions of $\mathrm{SiC}$ nanopowders mixed with $10 \mathrm{ml} 10 \%$ PVA $+5 \mathrm{ml}$ Triton X-100 phantom. The EDX analysis in Figure 3.24. supports this comment. The amount of $\mathrm{C}$ atom is higher than Si in EDX analysis. The number of $\mathrm{C}$ atoms from the $\mathrm{SiC}$ nanopowder composition and the content of the polyvinyl alcohol polymer of the formula $\left(\mathrm{C}_{2} \mathrm{H}_{4} \mathrm{O}\right)_{\mathrm{x}}$ is quite high compared to the $\mathrm{Si}$ atoms.

\section{References}

Joachimowicz, N., Duch, B., Conessa, C., \& Meyer, O. 2016. "Easy-to-produce adjustable realistic breast phantoms for microwave imaging", 10th European Conference on Antennas and Propagation (EuCAP), IEEE, 1-4.

Kottou, S., Nikolopoulos, D., Vogiannis, E., Koulougliotis, D.,Petraki, E. \& H Yannakopoulos, P. 2014. "How safe is the environmental electromagnetic radiation?", J Phys chem biophys, 4(3), 1-10.

Lam, A. R., Ding, H., \& Molloi, S. 2014. "Quantification of breast density using dual-energy mammography with liquid phantom calibration" Physics in medicine and biology, 52(14), 3985.

Lazebnik, M., Popovic, D., McCartney, L., Watkins, C.B., Lindstrom, M.J., Harter, J.,
Sewall, S.,Ogilvie, T., Magliocco, A., Breslin, T.M., Temple, W., Mew, D., Booske, J.H., Okoniewski, M. \& Hagness, S.C. 2007. "A large-scale study of the ultrawideband microwave dielectric properties of normal, benign and malignant breast tissues obtained from cancer surgeries", Physics in Medicine and Biology, 52(4), 6093-6115.

Lazebnik, M., 2008 "Ultrawideband spectroscopy and dielectric-properties contrast enhancement for microwave breast cancer detection and treatment", Unpublished Doctoral Thesis, University of Wisconsin, Madison.

Mayrovitz, H. N., Davey, S., \& Shapiro, E. 2008. "Local tissue water assessed dielectric constant: anatomical site and depth dependence in woman prior to breast cancer treatment-related surgery", Clinical Physiology and Functional Imaging, 28(5), 337-342.

Meo, S. D., M., Pasotti, I., Pasian, L., Matrone, G. 2018. "Realization of breast tissue-mimicking phantom materials: dielectric characterization in the $0.5-50$ $\mathrm{GHz}$ frequency range", IEEE/MTT-S International Microwave Biomedical Conference.

Meo, S. D., Iliopoulos, I., Pasian, M., Ettorre, M., Pasotti, L., Zhadobov, M., Matrone, G. 2019. “Tissue mimmicking materials for breast phantoms using waste oil hardeners", 13th European Conference on Antennas and Propagation (EuCAP).

Meo, S. D., Pasotti, L., Iliopoulos, I., Pasian, M., Ettorre, M., Zhadobov, M., \& Matrone, G. 2019. "Tissue-mimicking materials for breast phantoms up to 50 GHz", Physics in medicine and biology, 64(5), 1-13.

Ortega-Palacios, R., Leija, L., Vera, A., \& Cepeda, M. F. J. 2010. "Measurement of breast-tumor phantom dielectric properties for microwave breast cancer treatment evaluation", 7th International Electrical Engineering Computing Science and Automatic Control IEEE. 
Romeo, S., Di Donato, L., Bucci, O. M., Catapano, I., Crocco, L., Scarfî, M. R., \& Massa, R. 2011. "Dielectric characterization study of liquid-based materials for mimicking breast tissues", Microwave and Optical Technology Letters, 53(6), 1276-1280.

T.C. Milli Eğitim Bakanlığı. "Biyomedikal Cihaz Teknolojileri”, http://www.megep.meb.gov.tr/mte_progra m_modul/moduller_pdf/Mr\%20Fonksiyon\%20Testi.pdf, Son erişim tarihi: 25.07.2017

Xia, W., Piras, D., Heijblom, M., Steenbergen, W., Van Leeuwen, T. G., \& Manohar, S. 2011. "Poly (vinyl alcohol) gels as photoacoustic breast phantoms revisited", Journal of biomedical optics, 16(7), 075002. 